\title{
Taxonomic studies of centric diatoms (Diatomeae): unusual nanoplanktonic forms and new records for Brazil
}

\author{
Kaoli Pereira Cavalcante ${ }^{1,2}$, Priscila Izabel Tremarin ${ }^{1}$ and Thelma Alvim Veiga Ludwig ${ }^{1}$
}

Submitted: 2 February, 2012. Accepted: 13 August, 2012

\begin{abstract}
There have been few taxonomic studies of centric diatoms in lotic freshwater environments in Brazil, especially in terms of those including nanoplanktonic forms, which are often neglected in studies of local floras, because of their small size or confusing taxonomy. This is the first study focusing on centric diatoms in the flora of the state of Bahia, in northeastern Brazil. Plankton and periphyton attached to Eichornia crassipes were collected in the winter of 2009 in the Cachoeira River. The diatoms were analyzed and described under light and electron microscopies. Seventeen infrageneric taxa were identified. Cyclotella was represented by five taxa, and concerning of similarities between diacritical features of species in this genus, their descriptions were thoroughly detailed. This was the first time that Cyclotella atomus var. marina, previously recorded only in coastal areas of Japan and Korea, has been documented in a river in South America. We also identified two diatom taxa previously unrecorded in the flora of Brazil: C. cryptica and C. meduanae. Finally, we present a detailed light, transmission and scanning electron microscopy analysis of Skeletonema potamos, a diatom rarely found in the Brazilian literature.
\end{abstract}

Key words: Bahia, Coscinodiscophyceae, freshwater, Mediophyceae, river

\section{Introduction}

Taxonomic surveys provide a unique opportunity to detail the morphology of lesser-known species, such as small diatoms. These forms are difficult to identify, because the differences in their morphological structures are barely discernible under light microscopy (LM) (Kling \& Håkansson 1988). Although information about biodiversity represents a useful tool for ecological and applied studies, accurate identification is fundamental, because morphologically similar species can be ecologically distinct. Often, erroneous or inaccurate identifications may occur (Håkansson \& Kling 1994).

Cyclotella (Kützing) Brébisson comprises a complex of more than 100 species, including specimens with a small $(\leq 5 \mu \mathrm{m})$ diameter (Håkansson 2002). Taxonomy of this genus depends on the observation of frustule morphology under scanning electron microscopy (SEM), mainly of the smaller specimens, and the interspecific similarity is notable (Sabater \& Klee 1990). In order to clarify taxonomic questions regarding this complex, various studies have been conducted, some having resulted in the description of new species (Lowe 1975; Genkal \& Kiss 1993; Kiss et al. 2007; Sala \& Ramírez-R 2008).

In Brazil, there are few taxonomic studies focusing centric diatoms from lotic systems. Most of them have dealt with all diatom genera of periphytic community from the south and southeast regions of the country (Ludwig \& Valente-Moreira 1990; Ludwig \& Flôres 1995; Brassac et al. 1999; Landucci \& Ludwig 2005; Morandi et al. 2006; Tremarin et al. 2008; Tremarin et al. 2012). Only four previous studies of diatoms have been performed in the state of Bahia: Zimmerman (1913-1919) recorded approximately 200 marine and freshwater species; Moreira-Filho et al. (1995) recorded 92 marine and estuarine diatoms; and recently, two endemic species of Perinotia Metzeltin et Lange-Bertalot were recorded in the Chapada Diamantina region (Metzeltin \& Lange-Bertalot 2007; Ferrari et al. 2009). The Cachoeira River has been the focus of studies investigating water treatment (Fontes \& Araújo 2008), nutrient cycling (Lima et al. 2010) and protozoans (Pinto \& Boehs 2008; Silva et al. 2009), as well as assemblages of animals, such as decapod crustaceans (Almeida et al. 2006), fishes (Cetra et al. 2009) and mollusks (Ceuta et al. 2010). So far no algal communities have been investigated in this river.

The aim of this study was to investigate the centric diatoms found in the Cachoeira River. We focus on the morphological details of nanoplanktonic forms, adding new observations about the ultrastructure of Brazilian populations and new records to Bahia State as well as to Brazil.

\footnotetext{
${ }^{1}$ Universidade Federal do Paraná, Departamento de Botânica, Laboratório de Ficologia, Curitiba, PR, Brazil

${ }^{2}$ Author for corresponding: kaolicavalcante@gmail.com
} 


\section{Material and methods}

The Cachoeira River Basin belongs to eastern Bahia watersheds $\left(14^{\circ} 42^{\prime}-15^{\circ} 20^{\prime} \mathrm{S} ; 39^{\circ} 01^{\prime}-40^{\circ} 09^{\prime} \mathrm{W}\right)$. The drainage area is $4600 \mathrm{~km}^{2}$, with $24.1 \mathrm{~m}^{3} . \mathrm{s}^{-1}$ of mean annual discharge. The climate is tropical humid, with an average temperature of $24.6^{\circ} \mathrm{C}$ and annual rainfall exceeding $1300 \mathrm{~mm}$. The Cachoeira Basin rivers flow through 12 cities, which collectively have a population of 600,000 . Two counties, Itabuna and Ilhéus, are the economic and industrial centers of the state.

Sampling was conducted in July 2009, in the intermediate period between wet and dry seasons, in a shallow channel

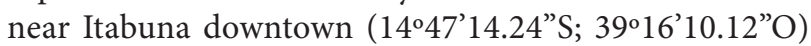
(Fig. 1), strongly influenced by the input of domestic sewage, approximately $25 \mathrm{~km}$ from the coast, with no salinity influence (Pinho 2001). Plankton was sampled with a $20 \mu \mathrm{m}$ mesh net, and periphyton attached to Eichornia crassipes (Martius) Solms-Laubach were collected by hand from the banks of the river.

The samples were fixed in $4 \%$ formaldehyde and cleaned according to Simonsen's method (1974) modified by Moreira-Filho \& Valente-Moreira (1981). Permanent slides were mounted with Naphrax ${ }^{\circledR}$ (refraction index $=1.74$; Brunel Microscopes Ltd., Wiltshire, UK). Diatoms were analyzed and measured using an Olympus $\mathrm{CH}$-2 light microscope (Olympus, Tokyo, Japan). Specimens illustrations were obtained with an Olympus BX-40 light microscope equipped with an Olympus DP71 digital camera (Olympus). Grids were analyzed under transmission electron microscopy (TEM) using a JEOL JEM 1200EXII microscope (JEOL, Ltd, Tokyo, Japan). Subsamples were mounted on stubs and sputter-coated with gold (SCD030 sputter coater; Balzers, Fürstentum, Liechtenstein). The scanning electron microscopy (SEM) was conducted using JEOL JSM 6360LV microscope (JEOL Ltd), at $15 \mathrm{kV}$ and $8 \mathrm{~mm}$ of working distance.

Morphological terminology was based on Barber \& Haworth (1981), Round et al. (1990) and Houk et al. (2010). The density of marginal striae and fultoportulae around the valve circumference were calculated according to Hasle (1983) modified by Syvertsen \& Hasle (1984). Samples and slides were housed at the Herbarium of the Federal University of Paraná (UPCB 65979, UPCB 65980) and the Diatom Herbarium of the Academy of Natural Sciences of Philadelphia (ANSP GC 26810).

\section{Results and discussion}

In this study, we observed 15 species and two non-typical varieties, included in eight genera of centric diatoms. Our descriptions follow.

Conticribra weissflogii (Grunow) Stachura-Suchoples et Williams, Eur. J. Phycol. 44(4): 482, 2009.

Figs. 2A-M

Valves circular with flat surface. Striae delicate, not discernible in LM. A ring of marginal fultoportulae interrupted by an evident rimoportula. Two to eight central fultoportulae, arranged in half circle or ring. Diameter: 12.5-21.9 $\mu \mathrm{m}$; marginal fultoportulae: 8.6-12.1 in $10 \mu \mathrm{m}$.

In TEM, the areolae are loculate, externally opened by irregular foramina, radially arranged. Internally, areolae are occluded by semi-continuous cribra (Figs. 2F). The cribra

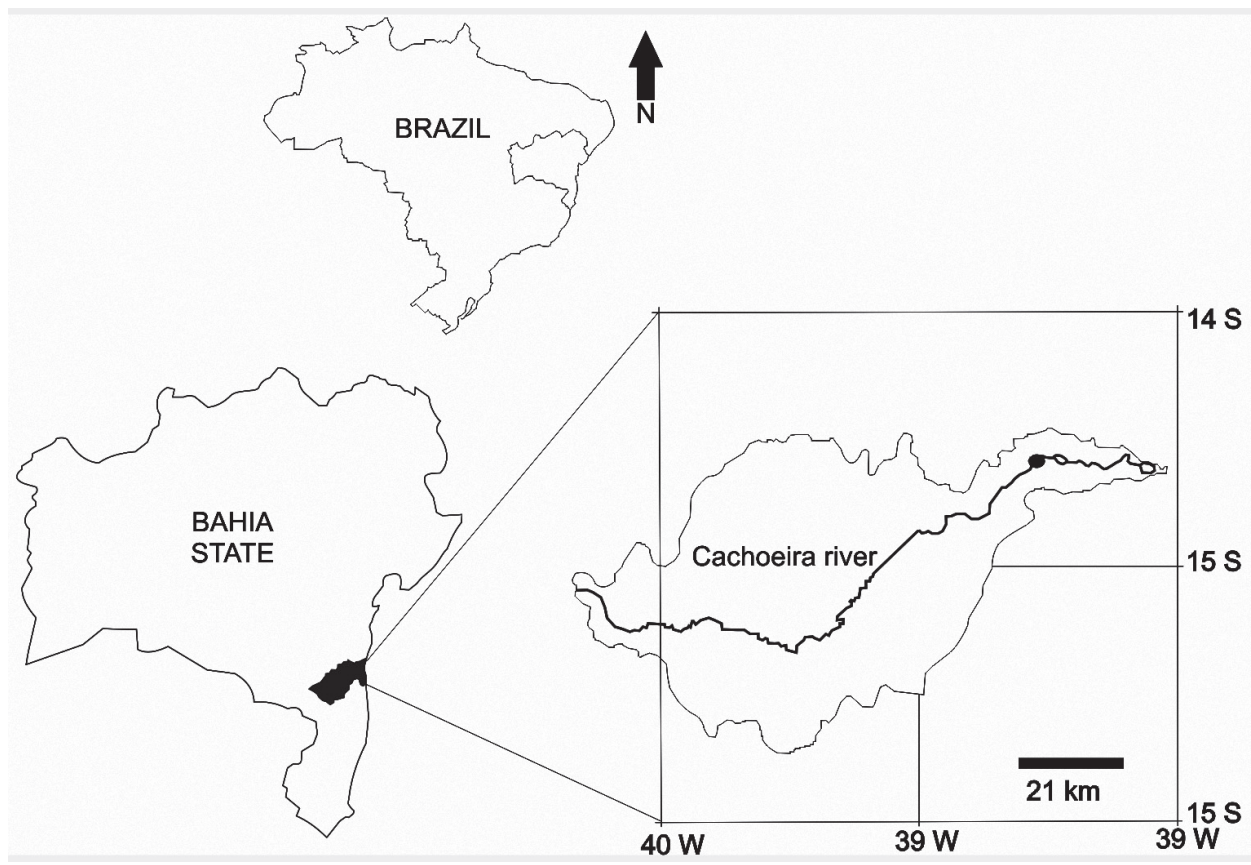

Figure 1. Study area: Cachoeira River, state of Bahia, Brazil. 
consist in circular, linearly arranged pores, ornamented by 13-15 marginal sectors and 1-2 central sectors (Fig. 2G). In SEM, the adjacent cells are linked by external tubes of marginal fultoportulae (Fig. $2 \mathrm{H}$ ). The species has valve surface ornamented by radial striae, composed by small and irregular areolae, intercalated by small nodules on the valve surface and mantle (Figs 2I-K). External tubes of fultoportulae are prolongated and ornate with ribs (Fig. 2K). Rimoportula has elongated external tube and is located slightly ahead of marginal fultoportulae ring (Fig. 2K). Internally, cribra are bi- to multiseriate and continue towards the mantle. Marginal and central fultoportulae show four satellite pores (Figs $2 \mathrm{~L}, \mathrm{M}$ ). The labiate process of rimoportula is large and pedunculated, radially oriented (Fig. 2M).

The recently proposed genus Conticribra groups freshwater and brackish water species of Thalassiosira Cleve with flat valve surfaces, continuous or semicontinuous cribra in loculate areolae and the rimoportula located at the valve margin, interrupting the ring of fultoportulae (Stachura-Suchoples \& Williams 2009). Morphological observations on C. weissflogii specimens collected in Brazil were provided by Torgan \& Santos (2006).

Skeletonema potamos (Weber) Hasle in Hasle et Eversen, J. Phycol. 12(1): 74, figs 1-17, 1976.

Figs. 3A-R

Frustules cylindrical, solitary or forming straight chains with two to three cells. Valves linked by short fultoportulae arranged in a marginal ring at valve surface. Numerous girdle bands, so that the pervalvar axis is larger than the valve diameter (Fig. 3A-F). Subcentral rimoportula present (Figs. 3G, H). Pervalvar axis: 4.4-7.3 $\mu \mathrm{m}$, diameter: 2.4-3.6 $\mu \mathrm{m}$.

In TEM, two opposite frustules are linked by interleaving of fultoportulae tubes, so what the distance between valve faces is short. Old girdle bands are also present between two linked frustules (Fig. 3I). The areolae are pseudoloculate, occluded by internal cribra. The cribra have minute pores (13-18 $\mathrm{nm}$ in diameter), radially arranged and perforated by sectors in a rosette pattern (Fig. 3J). In SEM, the frustules show valve surface ornate by small nodules and irregular areolae that extend across the entire mantle (Figs $3 \mathrm{~L}-\mathrm{N}$ ). Fultoportulae are located at the junction between the mantle and valve surface, in number of 4-5 (Figs 3L-N), with external tubes elongated and bipartite at the ends (Figs 3L, N). One subcentral rimoportula at valve surface shows small external tube (Figs 3K-M). Internally, the areolae occlusions are inconspicuous in SEM and the fultoportulae internal openings are not extended, with three small satellite pores (Figs 3O, P). The labiate process of rimoportula is short and sessile (Fig. 3O). Cingulum long, with open bands, ornate by rows of longitudinal pores (Figs $3 \mathrm{Q}, \mathrm{R}$ ).

In general, the $S$. potamos specimens analyzed here showed smaller frustules with fewer fultoportulae than did those collected in the south of Brazil and analyzed by Torgan et al. (2009) (3-4.5 $\mu \mathrm{m}$ diameter, 6-10 $\mu \mathrm{m}$ high and 5-7
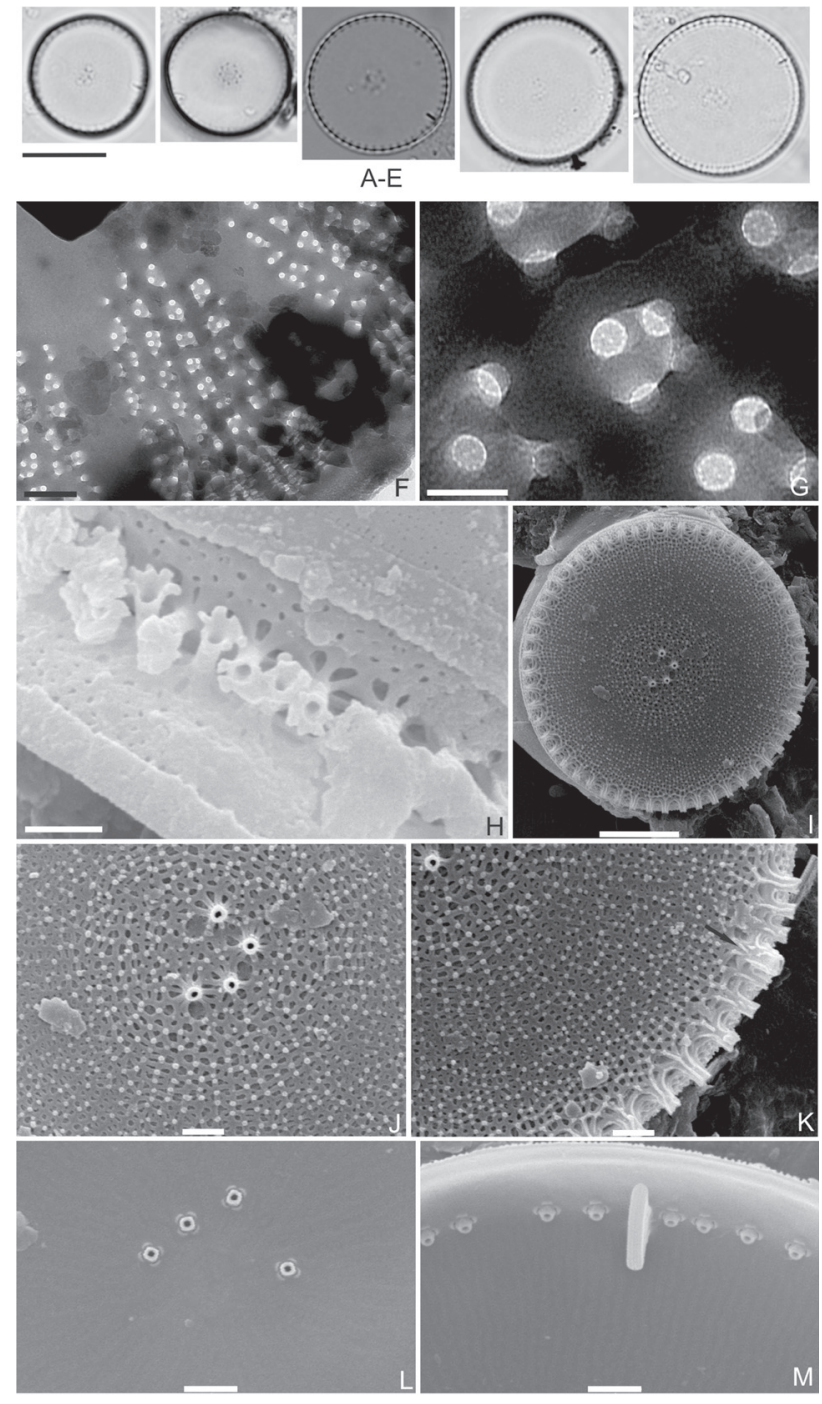

Figure 2. Conticribra weissflogii. A-E. Valve view, LM. F. Striae occlusions structure, TEM. G. Detail of the cribra perforation, TEM. H. Detail of junction between marginal fultoportulae of adjacent valves, in lateral view. I. External view of valve. J. External view of the central fultoportulae tubes. K. External view of the marginal fultoportulae and rimoportula (arrow). L. Internal view of central fultoportulae openings. M. Internal view of marginal fultoportulae and rimoportula openings. Scale bars $=10 \mu \mathrm{m}(\mathrm{A}-\mathrm{E}) ; 0.2 \mu \mathrm{m}(\mathrm{F}) ; 50 \mathrm{~nm}(\mathrm{G})$; $1 \mu \mathrm{m}(\mathrm{H}, \mathrm{J}-\mathrm{M})$; and $5 \mu \mathrm{m}$ (I).

marginal fultoportulae) and Bergersh et al. (2009) (3.5-4 $\mu \mathrm{m}$ diameter). We observed no concavity in the central region of valve surface and the fultoportulae showed relatively short external tubes, which is probably due to low salinity of the environment, as reported by Hasle \& Evensen (1976) and Torgan et al. (2009).

According to Sarno et al. (2005), the shape and position of the rimoportula are variable within the Skeletonema Greville genus. Intercalar valves show marginal rimoportula and terminal valves have subcentral or marginal rimoportula. In the material studied under electron microscopy, we found only terminal valves with eccentric rimoportulae, which have similar morphology to that described and illustrated 

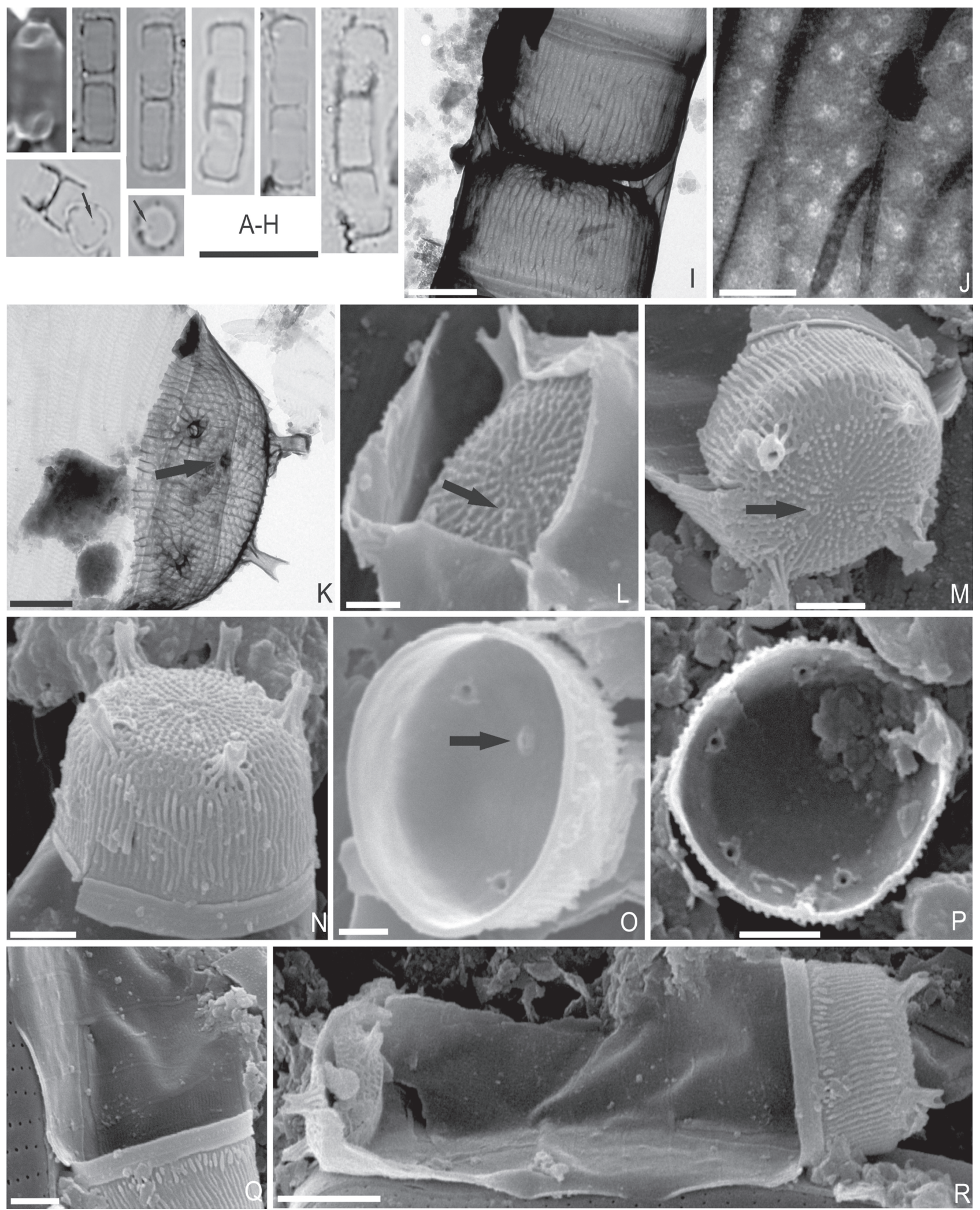

Figure 3. Skeletonema potamos. A-F. Chains in girdle view (A: phase contrast), LM. G, H. Valve view showing the external tubes of fultoportulae and subcentral rimoportula (arrows), LM. I. Detail of junction between marginal fultoportulae of adjacent valves and old girdle bands, in lateral view, TEM. J. Detail of the cribra perforation, TEM. K. Valve surface, showing subcentral rimoportula (arrow), TEM. L-M. External valve surfaces showing the external rimoportula opening (arrows), SEM. N. Frustule in girdle view showing the mantle structure and clefts at the distal tip of fultoportulae. $\mathbf{O}$. Internal view of valve, showing labiate process of rimoportula (arrow). P. Internal view of valve, showing internal fultoportulae openings and satellite pores. Q. Detail of girdle bands. R. Overview of girdle bands. Scale bars = $10 \mu \mathrm{m}(\mathrm{A}-\mathrm{H}) ; 1 \mu \mathrm{m}(\mathrm{I}, \mathrm{K}, \mathrm{M}, \mathrm{N}, \mathrm{P}, \mathrm{Q}) ; 100 \mathrm{~nm}(\mathrm{~J}) ; 0.5 \mu \mathrm{m}(\mathrm{L}, \mathrm{O})$; and $2 \mu \mathrm{m}(\mathrm{R})$. 
by Hasle \& Evensen (1976, Figs 21 and 28). Rimoportula close to marginal fultoportulae ring (corresponding to Fig. 20 of these authors) were not found. Because our specimens were solitary or formed short chains, we believe that the frequency of terminal valves was higher in our specimens than in those evaluated by Hasle \& Evensen (1976).

We found $S$. potamos in environmental conditions quite similar to those described in the species protologue (shallow channel influenced by domestic sewage), co-occurring with Cyclostephanos invisitatus (Hohn et Hellerman) Theriot, Stoermer et Håkansson (as Stephanodiscus invisitatus Hohn et Hellerman); Cyclotella atomus Hustedt, Cyclotella meneghiniana Kützing; and Discostella pseudostelligera (Hustedt) Houk et Klee (as Cyclotella pseudostelligera Hustedt) (Weber 1970).

Cyclotella atomus Hustedt var. atomus, Arch . Hydrobiol., Suppl. 15: 131-177, figs 9-12, 1937.

Figs 4A-P

Valves circular. Marginal striae radiate separated by costae. Marginal fultoportulae ring, fultoportulae distributed every 3 or 4 striae. One rimoportula inserted between two marginal fultoportulae. One subcentral fultoportulae. Diameter: 4.0-6.5 $\mu \mathrm{m}$, striae: $9.8-16.5$ in $10 \mu \mathrm{m}$, marginal fultoportulae: $2.8-4.6$ in $10 \mu \mathrm{m}$.

In SEM, valve surface is tangentially undulated (Figs $4 \mathrm{~K}, \mathrm{P}$ ) or flat (Fig. $4 \mathrm{M}$ ) at the central region and shows small nodules near to valve margin and mantle. Marginal fultoportulae are located at the face/valve mantle junction and do not show elongated external tubes (Figs 4K-M). Internally, striae are not alveolated (Figs $4 \mathrm{~N}, \mathrm{O}$ ). The marginal fultoportulae have two satellite pores and the central fultoportula has three (Figs $4 \mathrm{~N}, \mathrm{O}$ ). The labiate process of rimoportula is slightly oblique (Figs $4 \mathrm{~N}, \mathrm{O}$ ). The cingulum has open bands (Fig. 4P).

Our findings are consistent with the type material described by Håkansson \& Clarke (1997). Genkal \& Kiss (1993) observed samples from different localities and proposed C. atomus var. gracilis Genkal et Kiss, which differs from C. atomus var. atomus by the presence of marginal alveolar chambers, similar to those of $C$. meneghiniana.

Cyclotella atomus var. marina Tanimura, Nagumo et Kato, Bull. Natn. Sci. Mus., 30: 5-11, figs. 3-15, 2004.

Figs $5 \mathrm{~A}-\mathrm{G}$
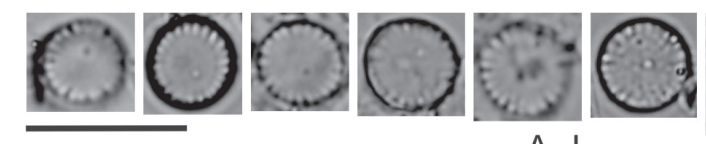

A-J
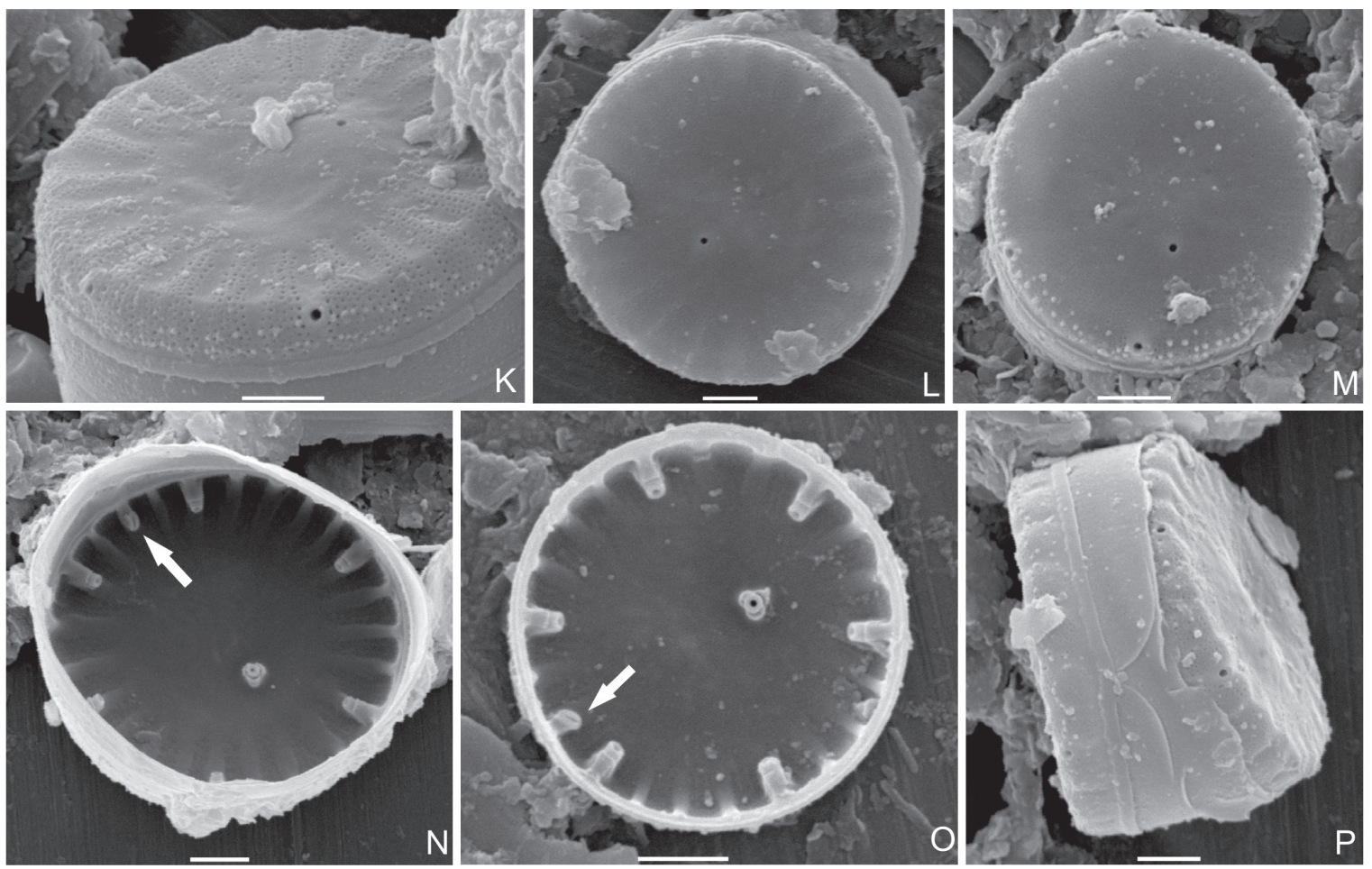

Figure 4. Cyclotella atomus var. atomus. A-J. Valve view, LM (phase contrast in J). K. External view of valve. Central area showing tangential undulation, SEM. L, M. Valve with flat surface, SEM. Note the granules on marginal area in M. N, O. Internal view of valve showing the orientation of rimoportula (arrows), SEM. P. Frustule in girdle view showing girdle bands, SEM. Scale bars $=10 \mu \mathrm{m}(\mathrm{A}-\mathrm{J})$ and $1 \mu \mathrm{m}(\mathrm{K}-\mathrm{P})$. 

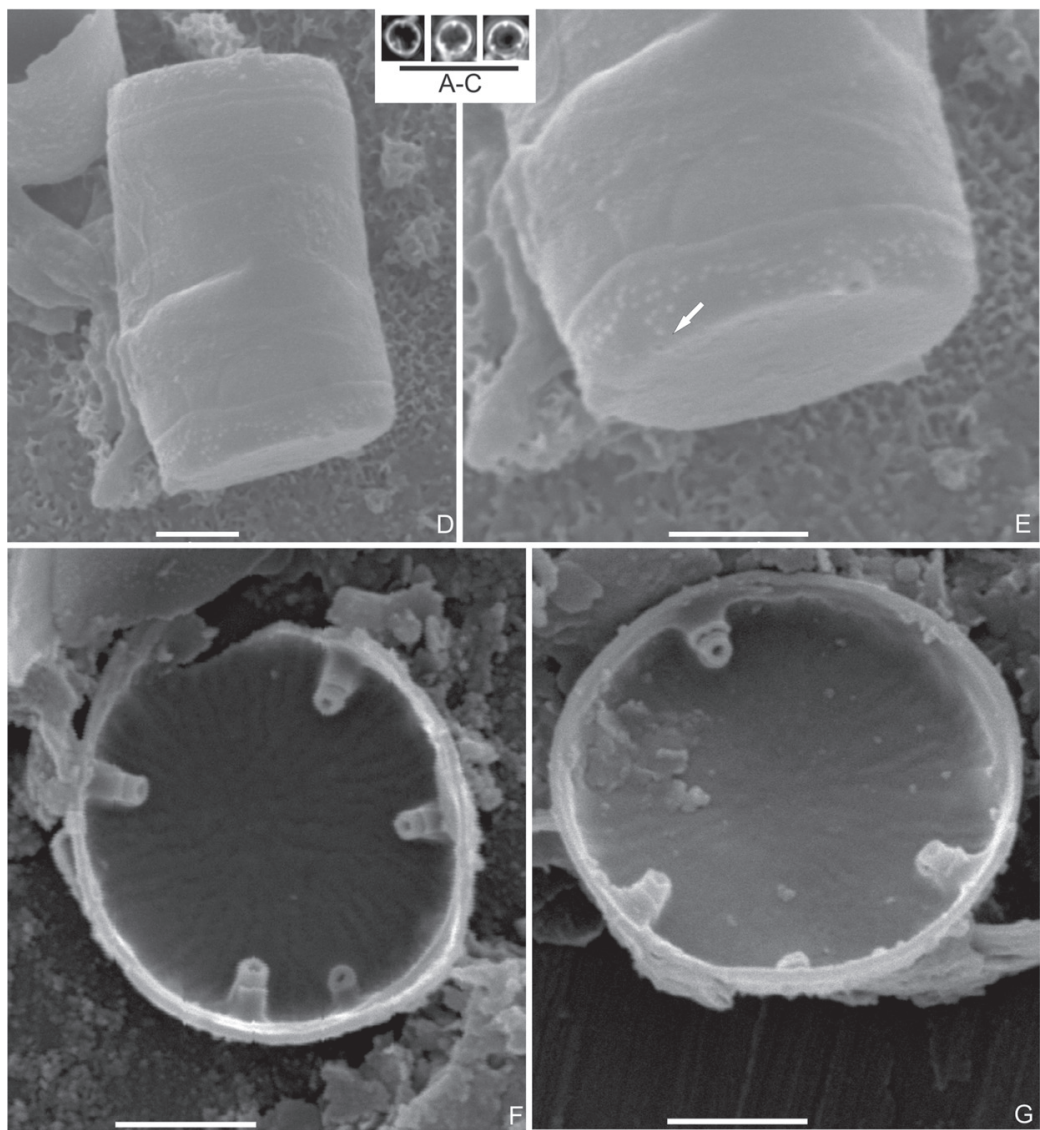

Figure 5. Cyclotella atomus var. marina. A-C. Valve view in phase contrast, LM. D. Frustule in girdle view, SEM. E. Valve surface and mantle showing the marginal fultoportulae and rimoportula openings (arrow), SEM. F, G. Internal view of valves showing the fultoportulae and rimoportula openings, SEM. Scale bars $=10 \mu \mathrm{m}(\mathrm{A}-\mathrm{C})$ and $1 \mu \mathrm{m}(\mathrm{D}-\mathrm{G})$.

Small circular valves. Striae inconspicuous. Marginal fultoportulae long and equidistant, with the inclusion of a marginal rimoportula among them. Central fultoportula absent. Diameter: $2.6-3.4 \mu \mathrm{m}$, fultoportulae: $3.0-4.2$ in $10 \mu \mathrm{m}$.

In SEM, valves show flat surface (Figs. 5D, E), ornate by delicate striae, $45-49$ in $10 \mu \mathrm{m}$ (Figs $5 \mathrm{E}-\mathrm{G}$ ) and granules scattered on the mantle (Fig. 5E). Three to four marginal fultoportulae at valve face/ mantle junction. External openings of fultoportulae are short and tangentially sectioned (Fig. 5E) and the internal openings are elongated and have two satellite pores radially oriented (Figs 5F, G). Rimoportula opens externally as a simple pore and internally with short peduncle, obliquely oriented (Figs 5E-G).

Cyclotella atomus var. marina differs from C. atomus var. atomus and C. atomus var. gracilis because it has no central fultoportula and because its costae are poorly developed (Tanimura et al. 2004). It is a characteristically small diatom that has previously been recorded only twice, both times in the northeastern Pacific Ocean: in Tokyo Bay (Tanimura et al. 2004) and on seagrasses in Korea (Chung et al. 2010). This is the first record of this taxon for freshwater systems in the Americas, indicating that it is allochthonous.
Cyclotella cryptica Reimann, Lewin et Guillard, Phycol. 3(2): 75-84, 1963.

Figs $6 \mathrm{~A}-\mathrm{K}$

Valves circular. Central area smooth. Marginal striae radiated. Fultoportulae irregularly arranged along the marginal ring but always associated to one costa, a single rimoportula is located at the ring of fultoportula. One central fultoportula. Diameter: 6.3-10.3 $\mu \mathrm{m}$, striae: 7-10 in $10 \mu \mathrm{m}$.

In SEM, the internal valve surface shows alveolate striae, but the alveoli are opened (Figs $6 \mathrm{H}-\mathrm{K}$ ). Therefore, the separation between the central and marginal areas is not so evident. Marginal fultoportulae ring arranged in the valve mantle, with short internal openings associated to three satellite pores, as well as the central fultoportula (Figs 6J, K). Pedunculated rimoportula with slightly oblique orientation (Fig. 6K). External surface was not observed.

Our morphometric data agree with those of Houk et al. (2010). C. cryptica is part of the morphologically confusing C. meneghiniana complex. Houk et al. (2010) suggested that those species could be conspecific. On the basis of molecular data, Beszteri et al. (2007) concluded that C. meneghiniana is a complex of sexual species that are reproductively isola- 

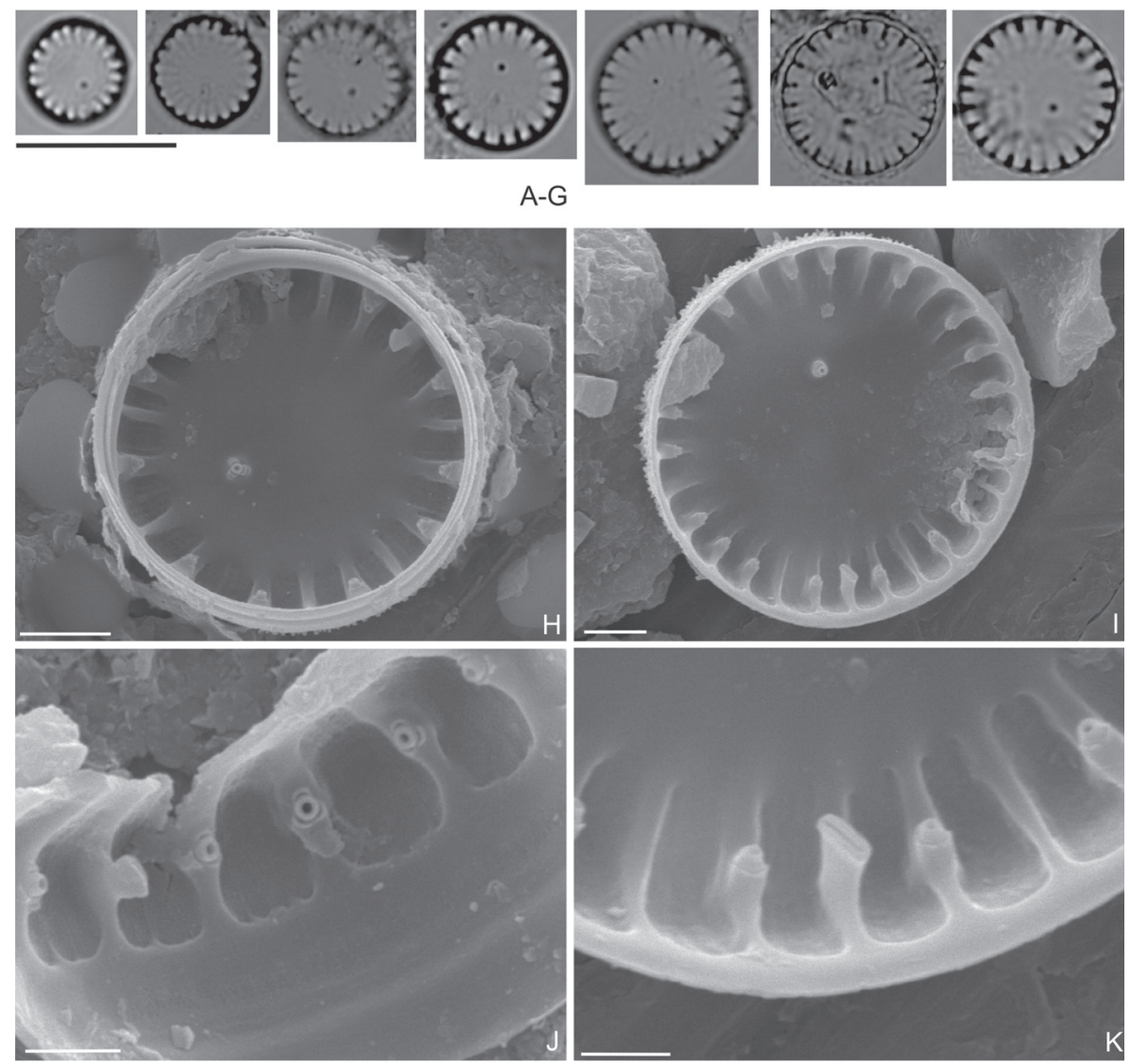

Figure 6. Cyclotella cryptica. A-G. Valve view, LM. H, I. Valves in internal view. J, K. Details of internal marginal fultoportulae and rimoportula openings. Scale bars $=10 \mu \mathrm{m}(\mathrm{A}-\mathrm{G}) ; 2 \mu \mathrm{m}(\mathrm{H}, \mathrm{I})$; and $1 \mu \mathrm{m}(\mathrm{J}, \mathrm{K})$.

ted, which explains the taxonomic separation between $C$. meneghiniana and C. cryptica, although their morphologies can overlap. In the present study, we were able to distinguish between C. cryptica and C. meneghiniana by the internally open alveoli and smaller, oblique rimoportula of the former, as stated in Houk et al. (2010).

Cyclotella meduanae Germain, Flore Diat. p. 36, pl. 8, fig. 28, pl. 154, figs. 4, 4a, 1981.

Figs 7A-Q

Valves circular. Marginal striae radiate. Marginal fultoportulae ring inserted every two or three striae. One rimoportula between two marginal fultoportulae. Central fultoportula absent. Diameter: 4.9-6.5 $\mu \mathrm{m}$, striae: 8.0-12.9 in $10 \mu \mathrm{m}$, marginal fultoportulae: $4.0-6.2$ in $10 \mu \mathrm{m}$.

In SEM, the external valve surface has a slight tangential undulation at central area, ornate by nodules (Figs 7L, M). Striae and interstriae are continuous with mantle (Fig. $7 \mathrm{~N}$ ). There are 4-9 rows of small and circular to irregular areolae per stria (Figs 7L, M). Marginal fultoportulae with short external tubes, rimoportula external aperture and small spines are located at the valve face/mantle junction (Fig. $7 \mathrm{~N}$ ). Internally, striae are not alveolated (Figs 7O-Q).
Fultoportulae have three satellite pores and labiate process of rimoportula is obliquely oriented (Figs 7P, Q).

The specimens observed are similar to that registered by Germain (1981), Håkansson \& Kling (1994), Tanaka (2007) and Sala \& Ramírez-R (2008). Our findings regarding valve diameter, striae and fultoportulae density are in agreement with data in the literature. However, within the Cachoeira River population, there were some smaller cells (valve diameter $4.9 \mu \mathrm{m} ; 8$ striae in $10 \mu \mathrm{m}$ ). C. meduanae is similar to the newly described species $C$. katiana Sala et Ramírez-R (valve diameter, 4.5-5.5 $\mu \mathrm{m}$; 4-6 marginal fultoportulae in $10 \mu \mathrm{m} ; 9-15$ striae in $10 \mu \mathrm{m}$ ), differing from the latter in that its striae are more elevated in relation to the valve surface (Sala \& Ramírez-R 2008).

Cyclotella meneghiniana Kützing, Die Kieselschaligen Bacillarien oder Diatomeen, p. 50, pl. 30, fig. 68, 1844.

Figs 8 A-O

Valves circular. Central area striated by grooves, radially disposed. Marginal striae radiated. Fultoportulae irregularly arranged along the marginal ring but always associated to one costa. Single rimoportula located in the ring of fultoportulae. One to three central fultoportulae. 

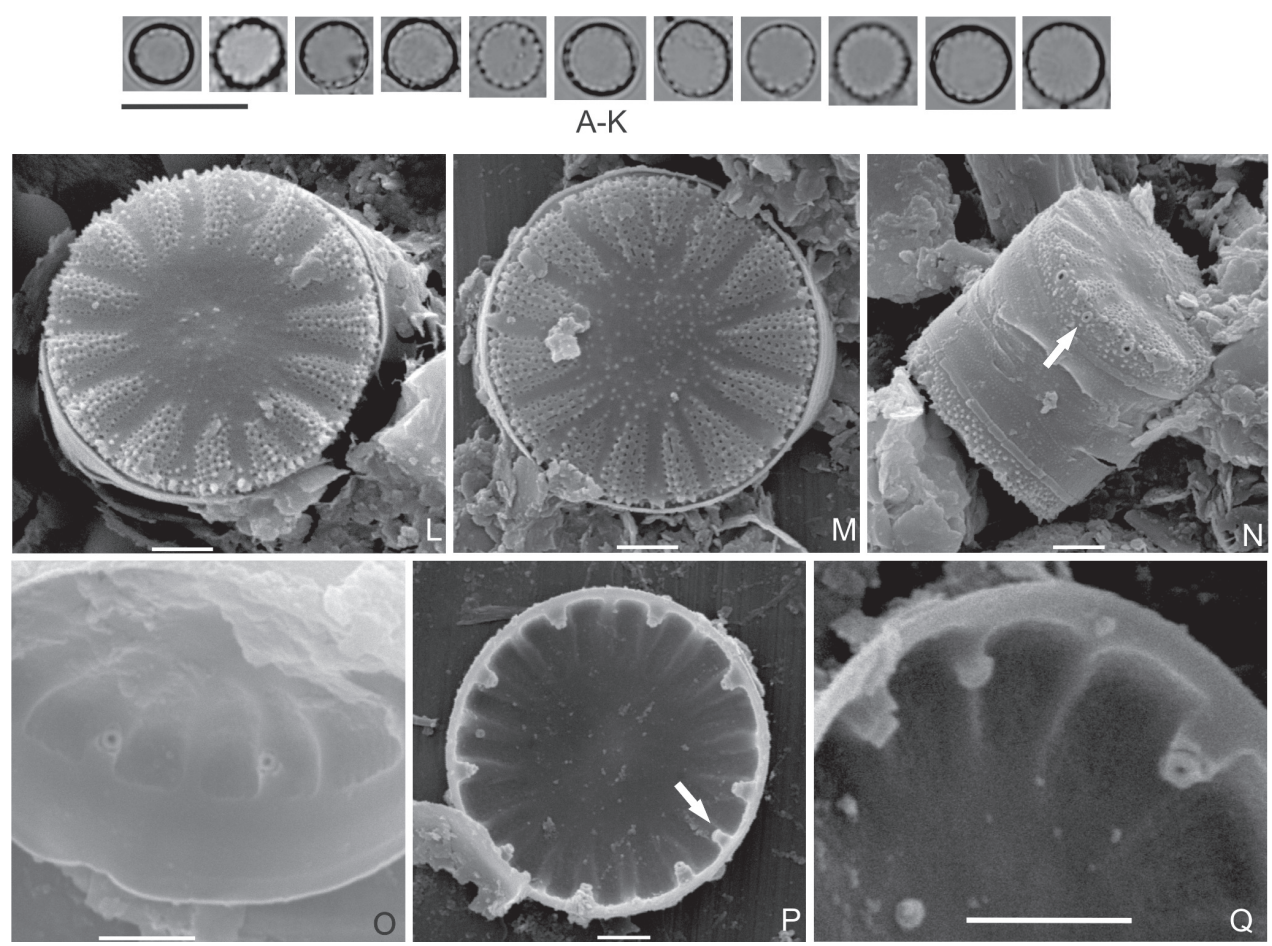

Figure 7. Cyclotella meduanae. A-K. Valve view, LM. L, M. External view of valve, SEM. N. Frustule in girdle view showing the bands and external rimoportula opening (arrow), SEM. O. Detail of valve internal view showing marginal fultoportulae surrounded by three satellite pores, SEM. P. Internal view of valve showing the orientation of rimoportula (arrow), SEM. Q. Detail of marginal rimoportula and fultoportulae, SEM. Scale bars $=10 \mu \mathrm{m}(\mathrm{A}-\mathrm{K})$ and $1 \mu \mathrm{m}(\mathrm{L}-\mathrm{Q})$.
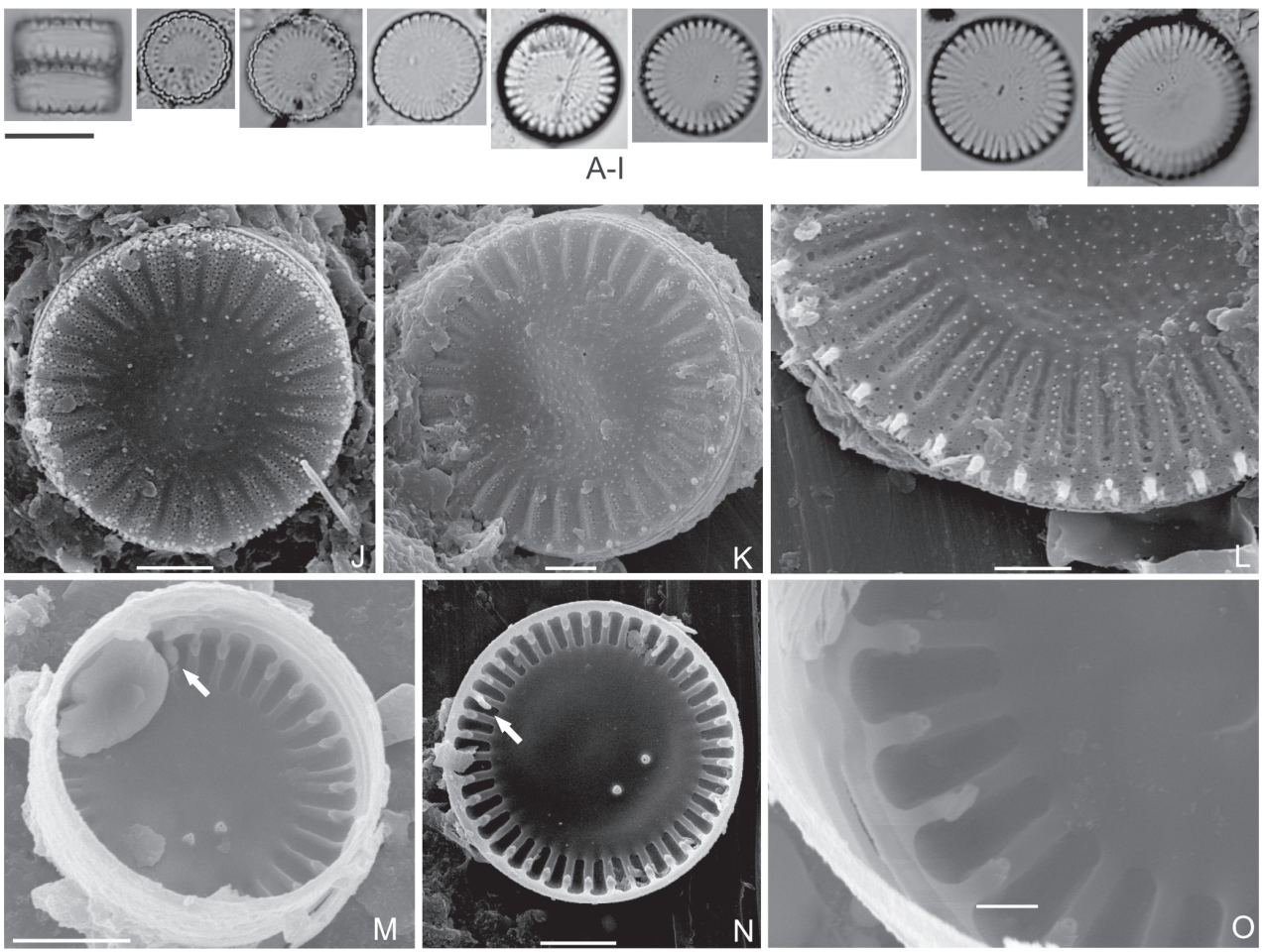

Figure 8. Cyclotella meneghiniana. A-I. Girdle (A) and valve views (B-I), LM. J, K. External view of valve, SEM. L. Detail of external fultoportulae opening with two adjacent spines, SEM. M-O. Valves in internal view showing marginal chambers, marginal and central fultoportulae and the orientation of rimoportula opening (arrows), SEM. Scale bars = $10 \mu \mathrm{m}$ (A-I); 2 $\mu \mathrm{m}(\mathrm{J}-\mathrm{L}) ; 5 \mu \mathrm{m}(\mathrm{M}, \mathrm{N})$; and $1 \mu \mathrm{m}(\mathrm{O})$. 
Diameter: $10.3-17.7 \mu \mathrm{m}$, pervalvar axis: $5.1-10.5 \mu \mathrm{m}$, striae: 5.8-8.3 in $10 \mu \mathrm{m}$.

In SEM, the external valve surface is granular and presents tangential undulation in central area (Figs 8J, $\mathrm{K})$. Striae with bundle of irregular areolae and granules among areolae (Figs 8J-L). Marginal fultoportulae ring arranged in the valve mantle, with external openings always associated to elongated spines (Fig. 8L). Internally, striae have developed alveoli (Figs 8M-O). Therefore, there is evident separation between the central and marginal areas. Marginal and subcentral fultoportulae have three satellite pores (Figs $8 \mathrm{M}-\mathrm{O}$ ). Pedunculated rimoportula, with a big labiate process, radially oriented (Figs $8 \mathrm{M}-\mathrm{O}$ ).

Discostella pseudostelligera (Hustedt) Houk et Klee, Diatom Res., 19(2): 223, 2004.

Figs $9 \mathrm{~A}-\mathrm{G}$

Valves circular. Valve surface flat. Marginal striae delicate, radially oriented and of equal length, sometimes with short striae among them. Central area with radial striae, rosette-shaped, $1 / 2$ of the valve diameter. Marginal fultoportulae equidistant, marginal rimoportula not observed. Diameter: 4.3-6.0 $\mu \mathrm{m}$, striae: 17.2-21.0 in $10 \mu \mathrm{m}$, marginal fultoportulae: $3.6-4.7$ in $10 \mu \mathrm{m}$.

In SEM, valves have flat surface (Figs 9E-G), ornamented by delicate striae, each one with two rows of areolae (Figs 9F-G). Six to seven fultoportulae distributed in a marginal ring at the mantle and valve surface junction. External tubes of fultoportulae are short and tangentially sectioned at the opening (Fig. 9E).

Houk et al. (2010) analyzed the type material of $D$. pseudostelligera and D. woltereckii (Hustedt) Houk et Klee and concluded that the valve morphology of the two species overlaps. Valves from type material of both species differ only in terms of the stellate pattern of the valve center: in $D$. pseudostelligera, the central area is broad and the marginal striae are of equal length; in $D$. woltereckii, the central area is smaller and the marginal striae are dichotomous (Houk et al. 2010). Our specimens match the type material of $D$. pseudostelligera. There is also an ecological difference between these two species: $D$. pseudostelligera is mainly a temperate species, whereas D. woltereckii is mainly tropical (Houk et al. 2010). However, there are records of D. pseudostelligera in northern Brazil, which has a tropical climate (Eskinazi-Leça et al. 2012). Therefore, the morphological and geographical boundaries between these two taxa need to be clarified. Similarities were also found between D. pseudostelligera and Thalassiosira pseudonana Hasle et Heimdal in terms of striae pattern and valve diameter. However, according to Hasle \& Heimdal (1970) and Garcia \& Odebrecht (2009), T. pseudonana often has a subcentral fultoportula and has a higher number of marginal fultoportulae (6-12 in $10 \mu \mathrm{m})$, as well as having a sessile rimoportula.
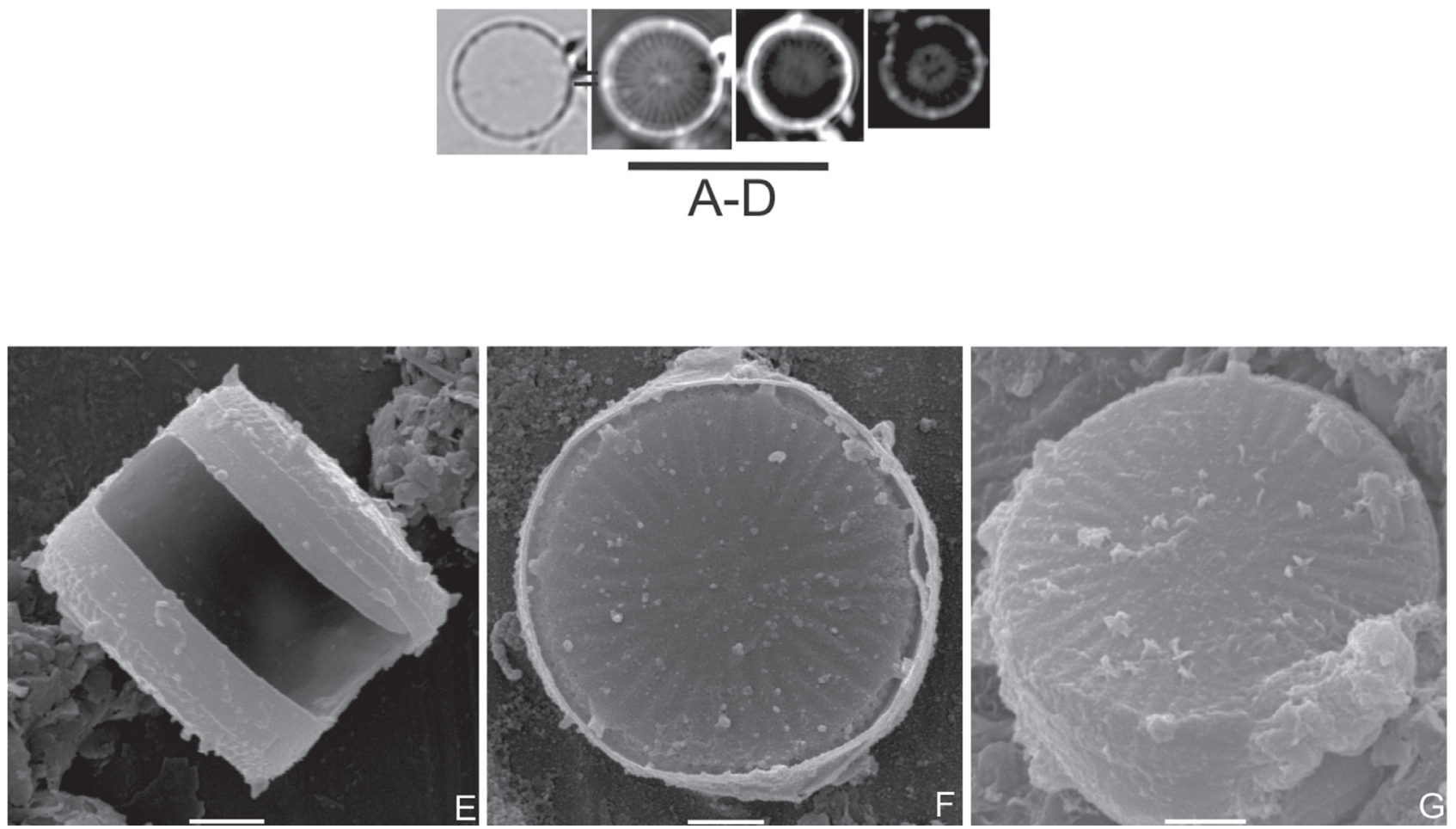

Figure 9. Discostella pseudostelligera. A-D. Valve view, LM (phase contrast in B-D). E. Frustule in girdle view. F, G. External view of valve. Scale bars $=10 \mu \mathrm{m}(\mathrm{A}-\mathrm{D})$ and $1 \mu \mathrm{m}(\mathrm{E}-\mathrm{G})$. 
Cyclostephanos invisitatus (Hohn et Hellerman) Theriot, Stoermer et Håkansson, Diatom Res. 2(2): 256-257, figs 18-24, 1987.

Figs 10A-L

Valves circular. Valve surface flat. Striae radial and delicate, evident only at the margins. Subcentral fultoportula present. Marginal fultoportulae and rimoportula indistinct. Diameter: 7.3-8.9 $\mu \mathrm{m}$, striae: 12.9-17.2 in $10 \mu \mathrm{m}$.

In SEM, the valve surface has slightly concentric undulation (Fig. 10G) and radial striae, uniseriate in central region and multiseriate toward the margins, which adorn the entire valve surface (Figs 10G, H). Interstriae discernible only in the marginal area of valve (Figs 10G, H), branching at the mantle (Fig. 10I). Elongated marginal spines at the mantle and valve surface junction (Figs 10G-I). Ring of fultoportulae located in mantle, with simple pore shaped external tubes (Fig. 10I). Rimoportula is on the mantle, beneath one spine (Fig. 10H). Internally, the areolae are occluded by cribra, which is domed in central area and flat towards the margins and mantle (Figs 10J, K). Interstriae are not raised internally. Subcentral and marginal fultoportulae have two satellite pores (Figs 10J-L). Internal view of rimoportula are small and sessile (Fig. 10J).

Theriot et al. (1987) analyzed the type material of $C$. invisitatus from north American rivers which agreed in morphometrical features with our specimens $(6-8 \mu \mathrm{m}$ in diameter, 17 striae in $10 \mu \mathrm{m}$ - measured from the Fig. 19, Theriot et al. 1987). This species is similar to C. damasi (Hustedt) Stoermer et Håkansson, C. costatilimbus (Kobayasi et Kobayashi) Stoermer, Håkansson et Theriot and C. tholiformis Stoermer, Håkansson et Theriot. However, C. costatilimbus has no branched mantle interstriae; and the internal interstriae of C. damasi and C. tholiformis are raised, whereas those of $C$. invisitatus are flat (Stoermer et al. 1987; Theriot et al. 1987).

Melosira varians Agardh, Bot. Zeit., p. 628, 1827. Fig. $11 \mathrm{~A}$

Frustules cylindrical in girdle view, linked by valve surface in straight chains. Areolae inconspicuous. Valve surface not observed. Pervalvar axis: 23.5-26.7 $\mu \mathrm{m}$, diameter: $17.0-20.2 \mu \mathrm{m}$.

Aulacoseira ambigua (Grunow) Simonsen, Bacill. 2: 56, 1979.

Figs 11B-F

Frustules cylindrical, linked in straight chains by small spines located at the valve face/mantle junction. Striae in the mantle arranged obliquely in relation to pervalvar axis.
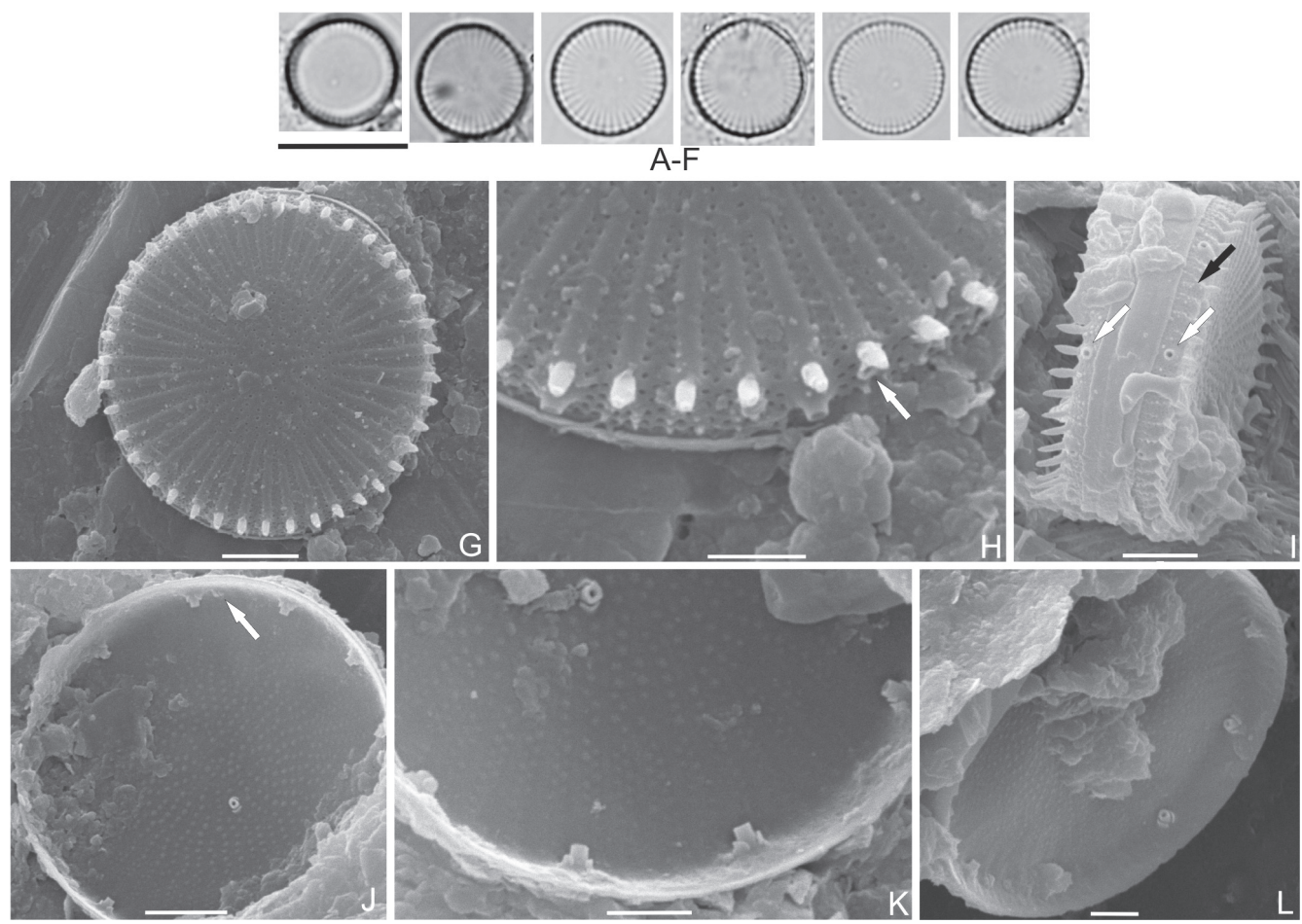

Figure 10. Cyclostephanos invisitatus. A-F. Valve view, LM. G. External overview of valve. H. Detail of the marginal spines, showing external fultoportulae and rimoportula (arrow) openings. I. Frustule in girdle view showing the marginal fultoportulae openings (white arrows) and interstria branching on mantle (black arrow). J. Valve in internal view, showing internal opening of rimoportula (arrow). K, L. Details of internal opening of marginal and subcentral fultoportulae. Scale bars $=10 \mu \mathrm{m}(\mathrm{A}-\mathrm{F}) ; 2 \mu \mathrm{m}$ $(\mathrm{G}, \mathrm{I}, \mathrm{J})$; and $1 \mu \mathrm{m}(\mathrm{H}, \mathrm{K}, \mathrm{L})$. 
Rounded areolae. Pronounced sulcus. Mantle height: 8.1$11.8 \mu \mathrm{m}$, diameter: $3.9-8.9 \mu \mathrm{m}$, striae : $12.7-19.7$ in $10 \mu \mathrm{m}$, areolae: $14-16$ in $10 \mu \mathrm{m}$.

Aulacoseira granulata (Ehrenberg) Simonsen var. angustissima (O. Müller) Simonsen, Bacill. 2: 58, 1979.

Figs 11G-I

Frustules cylindrical united by small linking spines in straight chains. Terminal valves with elongated separation spines. Striae in the mantle obliquely arranged in relation to pervalvar axis in intercalary cells, and parallel in terminal cells. Rounded and delicate areolae. Sulcus slightly pronounced. Mantle height: 12.9-14.6 $\mu \mathrm{m}$; diameter: $4.0 \mu \mathrm{m}$, striae: 14.8-17.3 in $10 \mu \mathrm{m}$, areolae: $14.8-19.7$ in $10 \mu \mathrm{m}$.

Aulacoseira granulata (Ehrenberg) Simonsen var. granulata, Bacill. 2: 58, 1979.

Figs 11J-K

Frustules cylindrical united in straight chains. Elongated separation spines present in terminal valves. Striae in the mantle arranged parallel to pervalvar axis in terminal cells. Intercalary cells not observed. Coarse rounded areolae. Sulcus slightly pronounced. Mantle height: 21.9-23.5 $\mu \mathrm{m}$, diameter: $12.1-12.9 \mu \mathrm{m}$, striae: 8 in $10 \mu \mathrm{m}$, areolae: 7 in $10 \mu \mathrm{m}$.

Aulacoseira herzogii (Lemmermann) Simonsen, Bacill. 2: 59, 1979.

Figs 11L-N

Frustules cylindrical linked in straight chains by two long marginal spines in the valve. Mantle striae inconspicuous. Sulcus slightly pronounced. Mantle height: $9.3 \mu \mathrm{m}$; diameter: $4.0 \mu \mathrm{m}$.

Aulacoseira pusilla (F. Meister) Tuji et Houk, Bull. Nat. Sci. Mus., Ser. B (Botany), 30(2): 38, 2004.

Fig. 110

Frustules cylindrical linked in chains by small marginal spines. Striae in the mantle curved, obliquely arranged in relation to pervalvar axis. Rounded areolae. Sulcus slightly pronounced. Mantle height: 2.8-3.2 $\mu \mathrm{m}$, diameter: 4.9-5.7 $\mu \mathrm{m}$, striae: $17.3-20.1$ in $10 \mu \mathrm{m}$. The specimens found were slightly smaller than those registered by Tuji \& Houk (2004), who recorded valve diameters of 6.0-10.0 $\mu \mathrm{m}$. However, our population presents morphometric data more similar to protologue specimens of $A$. subborealis (Nygaard) Denys, Muylaert et Krammer, synonymized with $A$. pusilla by Tuji \& Williams (2007), which had 4-7 $\mu \mathrm{m}$ in diameter (Denys et al. 2003).

Aulacoseira tenella (Nygaard) Simonsen, Bacill. 2: 9-71, 1979.

Figs 11P-Q
Frustules cylindrical linked in chains by small marginal spines. Valve surface completely areolate. Striae in the mantle arranged parallel in relation to pervalvar axis. Rounded areolae. Sulcus not pronounced. Mantle height: $1.4 \mu \mathrm{m}$, diameter: 5.0-6.4 $\mu \mathrm{m}$.

Our morphometric data are consistent with those reported by Raupp et al. (2006), who identified A. tenella in a reservoir in southern Brazil.

Pleurosira laevis (Ehrenberg) Compère var. laevis, Bacill. 5: 177-178, 1982.

Figs $12 \mathrm{~A}-\mathrm{G}$

Frustules cylindrical. Valve surface flat to slightly convex, circular to subcircular. Two marginal and opposite ocelli present in each valve, in the plane of valve surface. Striae radial with rounded areolae. Two rimoportulae in the subcentral valve region, opposite located to the ocelli. Larger diameter: 46.2-59.9 $\mu \mathrm{m}$, smaller diameter: 42.1-51.8 $\mu \mathrm{m}$, striae: $14-17$ in $10 \mu \mathrm{m}$, areolae: $15-18$ in $10 \mu \mathrm{m}$.

Under SEM, we observed external surface ornamented with short acute verrucae (Fig. 12C). The ocelli are elliptical, surrounded by an irregular rim, with diminute poroids (Fig. 12C). Internally, simple round areolae and sessile rimoportula (Fig. 12D). Valvocopulae fimbriate (Figs 12E-G).

All the seventeen identified taxa from Cachoeira River represent new records for the state of Bahia. Cyclotella atomus var. marina, C. cryptica and C. meduanae are new for rheophilic environments in Brazil. Worldwide, this is the third record of C. atomus var. marina, which has previously been recorded only in coastal regions of the northeastern Pacific (Tanimura et al. 2004; Chung et al. 2010).

We also registered $S$. potamos for the first time in the northeastern Brazil. This species was previously found only in the south of the country: in Patos Lagoon (Bergesch et al. 2009; Torgan et al. 2009); in Mirim Lake (Pérez \& Odebrecht 2005); and in the Jacuí River Delta (Laux \& Torgan 2011). Cyclostephanos invisitatus and Cyclotella atomus have also been reported only in southern Brazil (Tremarin et al. 2009; Eskinazi-Leça et al. 2012), whereas Cyclotella meneghiniana, Discostella pseudostelligera, Melosira varians, Pleurosira laevis and Aulacoseira spp. seem to have a wider distribution in the country (Eskinazi-Leça et al. 2012).

The species richness of diatoms is higher in the Cachoeira River than in other rivers previously studied in Brazil (Ludwig \& Valente-Moreira 1990; Ludwig \& Flôres 1995; Landucci \& Ludwig 2005). The specific composition found was similar to those recorded by Weber (1970) in the Little Miami River, in the USA; by Sabater \& Klee (1990) in the Ebro River, in Spain; and by Belcher \& Swale (1978) in rivers in England and France. The species recorded are commonly found in plankton in high-nutrient environments (Sabater \& Klee 1990).

Because nanoplankton species are quite small, they are difficult to distinguish during LM analysis. Meticulous 


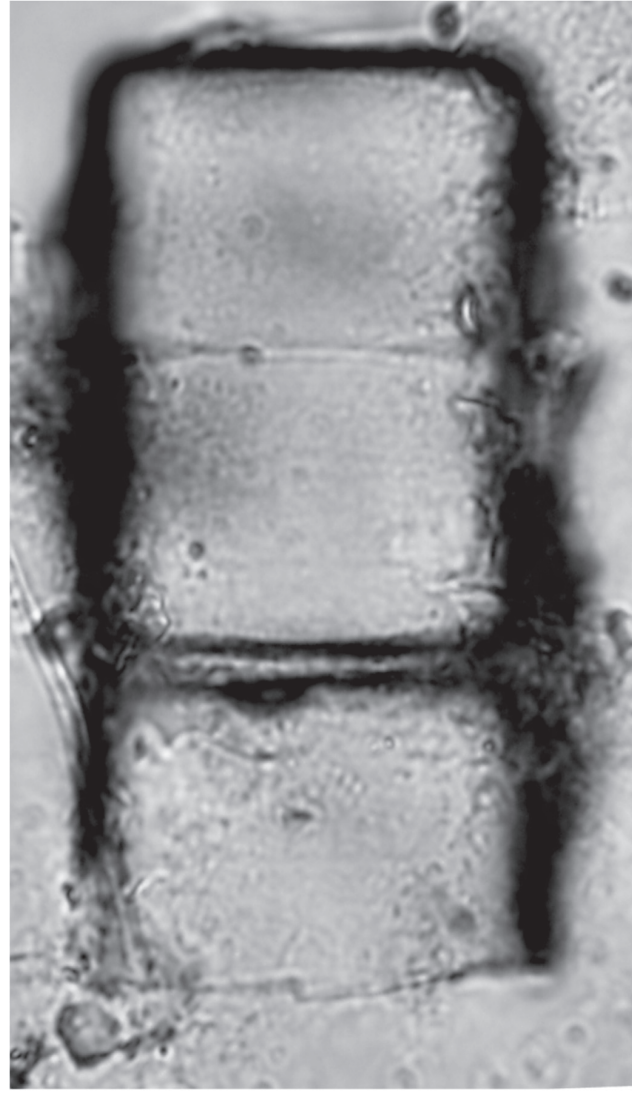

A

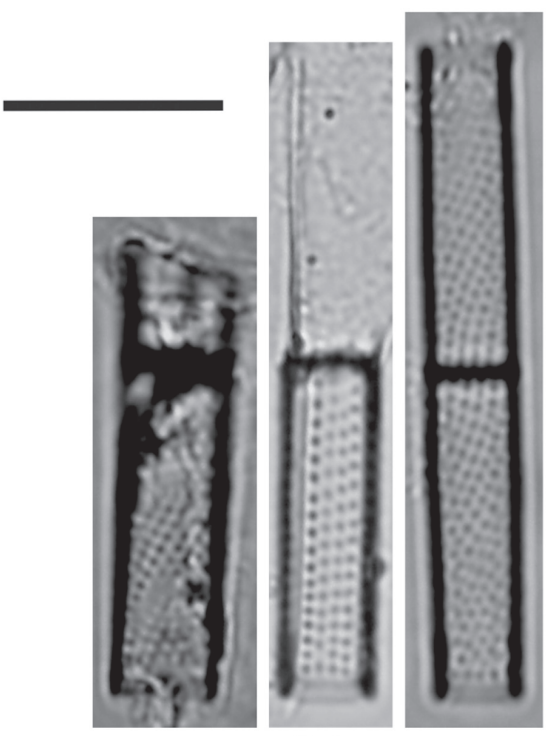

G-I
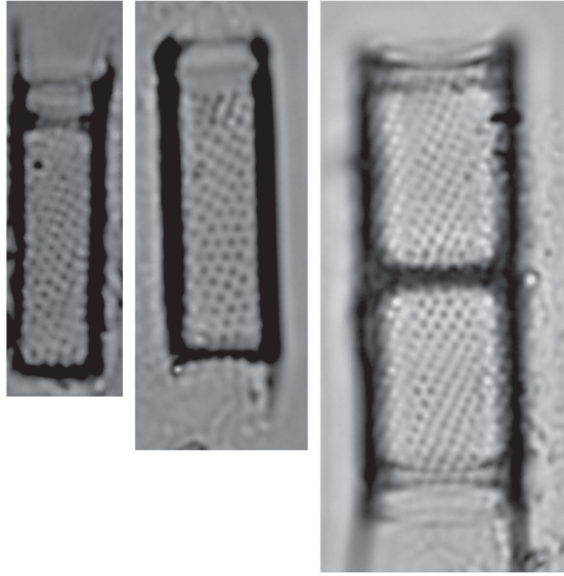

B-F

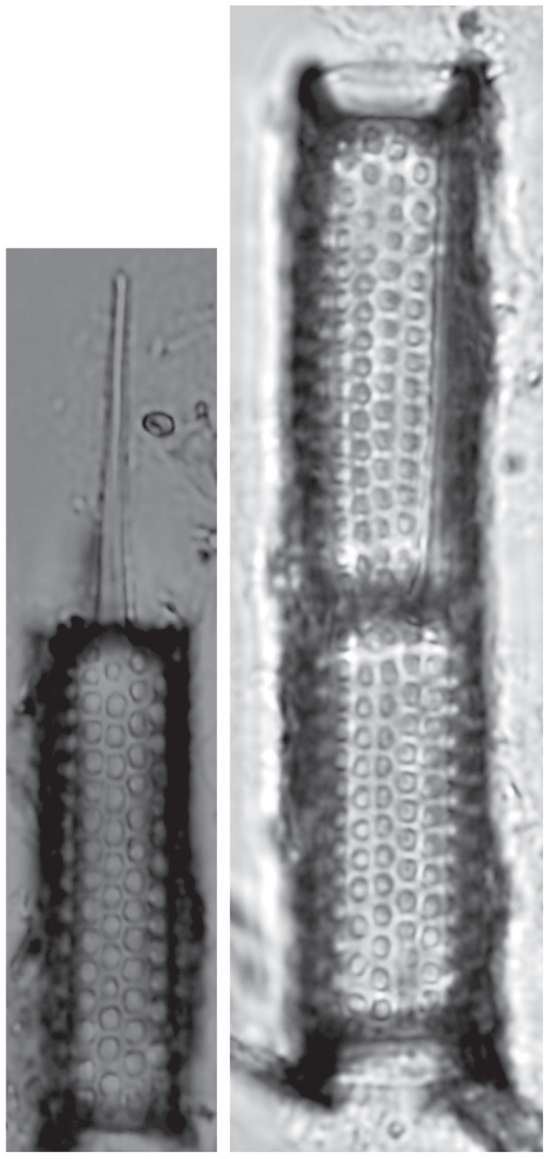

$\mathrm{J}-\mathrm{K}$
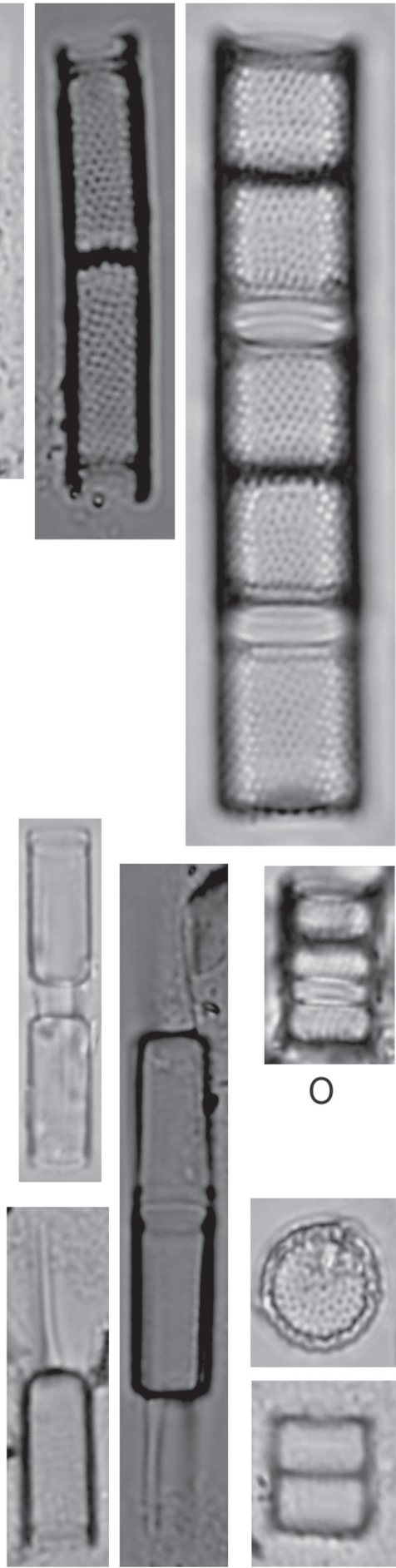

L-N
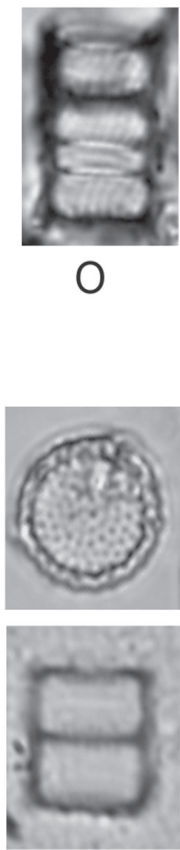

$P-Q$

Figure 11. Melosira and Aulacoseira species, LM. A. Melosira varians in girdle view. B-F. Aulacoseira ambigua in girdle view. G-I. A. granulata var. angustissima in girdle view. J, K. A. granulata var. granulata in girdle view. L-N. A. herzogii in girdle view. O. A. pusilla in girdle view. P, Q. A. tenella in valve and girdle view, respectively. Scale bar $=10 \mu \mathrm{m}$. 

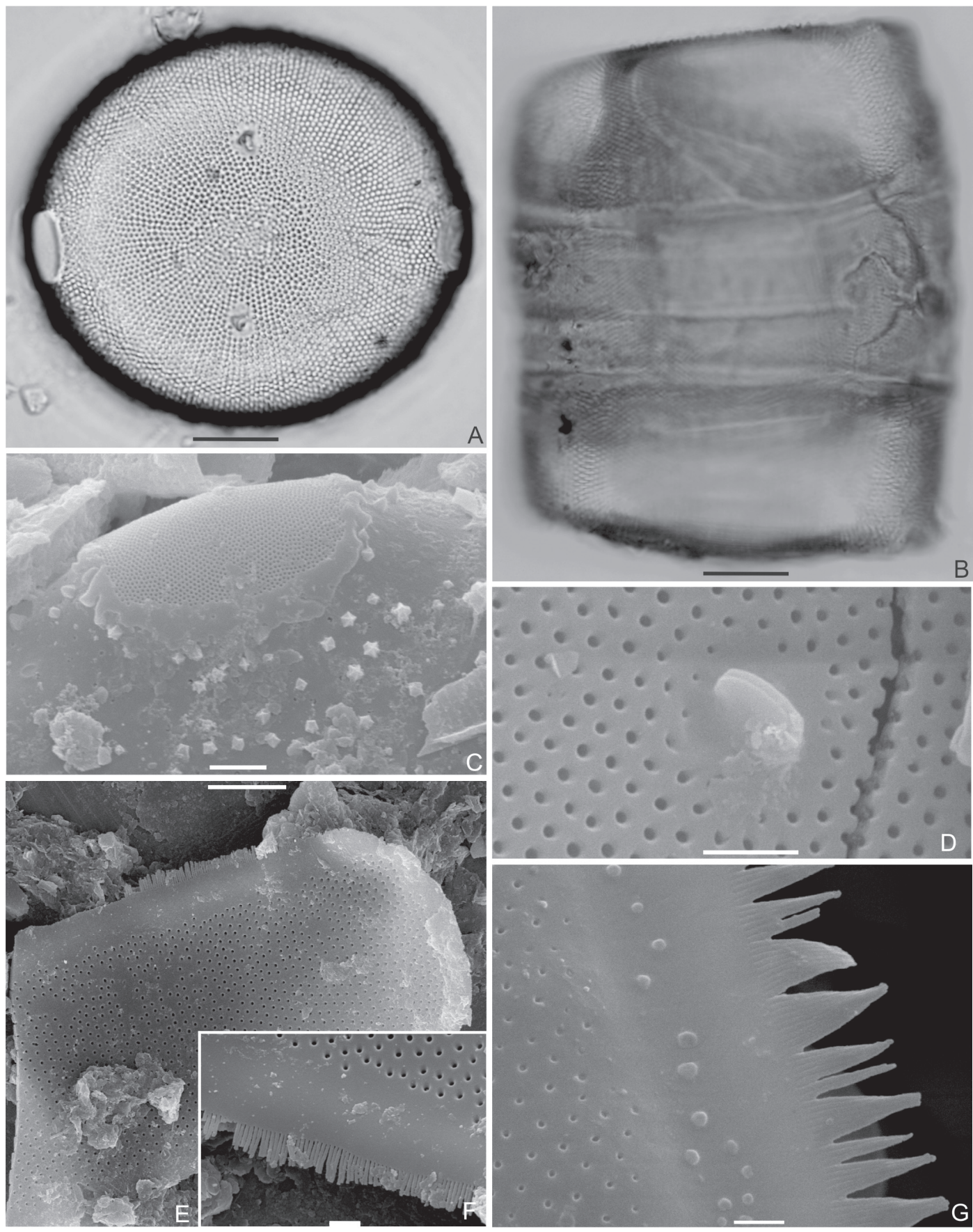

Figure 12. Pleurosira laevis var. laevis. A, B. Valve and girdle view, respectively, LM. C, D. Valve structure. C. External view of ocellus. D Internal view of a rimoportula. E-G. Valvocopulae structure, SEM. E. Overview of valvocopula. F, G. Detail of fimbriate margin. Scale bars $=10 \mu \mathrm{m}(\mathrm{A}, \mathrm{B}) ; 2 \mu \mathrm{m}(\mathrm{C}, \mathrm{D}) ; 5 \mu \mathrm{m}(\mathrm{E})$; and $1 \mu \mathrm{m}(\mathrm{F}, \mathrm{G})$.

taxonomic study is necessary because the distinguishing features are usually discrete and visible only under SEM. Finally, we believe that the limited distribution reported for these diminutive forms in Brazil is attributable not only to a lack of extensive geographical sampling but also to the scarcity of expert diatom taxonomists engaged in analyzing the species occurring in the country.

\section{Acknowledgments}

The authors are grateful to the Electron Microscopy Center of the Universidade Federal do Paraná (UFPR, Federal University of Paraná) for making the SEM analysis possible, to Eduardo Freire for assisting in the map design, and to Dr. Václav Houk (of the Czech Republic) for the inestimable contributions to the Cyclotella taxonomy. This 
study received financial support from the Brazilian Coordenação de Aperfeiçoamento de Pessoal de Nível Superior (CAPES, Office for the Advancement of Higher Education; postgraduate scholarships to Kaoli Cavalcante and Priscila I. Tremarin) and Conselho Nacional de Desenvolvimento Científico e Tecnológico (CNPq, National Council for Scientific and Technological Development; scientific productivity grant to Thelma A. V. Ludwig).

\section{References}

Almeida, A.O.; Coelho, P.A.; Santos, J.T.A. \& Ferraz, N.R. 2006. Estuarine Decapod Crustaceans from Ilhéus, State of Bahia, Brazil. Biota Neotropica 6(2): 1-24.

Barber, H.G. \& Haworth, E.Y. 1981. A guide to the morphology of the diatom frustule. The Freshwater Biological Association 44: 1-112.

Belcher, J.H. \& Swale, E.M.F. 1978. Skeletonema potamos (Weber) Hasle and Cyclotella atomus Hustedt (Bacillariophyceae) in the plankton of rivers in England and France. European Journal of Phycology 13(2): 177-182

Bergesh, M.; Garcia, M. \& Odebrecht, C. 2009. Diversity and morphology of Skeletonema species in southern Brazil, southwestern Atlantic Ocean. Journal of Phycology 45: 1348-1352.

Beszteri, B.; John, U. \& Medlin, L.K. 2007. An assessment of cryptic genetic diversity within the Cyclotella meneghiniana species complex (Bacillariophyta) based on nuclear and plastid genes, and amplified fragment length polymorphisms. European Journal of Phycology 42(1): 47-60.

Brassac, N.M.; Atab, D.R.; Landucci, M.; Visinoni, N.D. \& Ludwig, T.A.V. 1999. Diatomáceas cêntricas de rios da região de abrangência da usina hidrelétrica de Salto Caxias, PR (Bacia do rio Iguaçu). Acta Botanica Brasilica 13(3): 277-289.

Cetra, M.; Ferreira, F.C. \& Carmass, A.L. 2009. Characterization of the fish assemblages in headwaters streams in the rainy season in the Cachoeira river basin (SE of the Bahia, NE of the Brazil). Biota Neotropica 9(2): 107-115.

Ceuta, L.O.; Boehs, G. \& Santos, J.J.B. 2010. Hermaphroditism among dioecious Tagelus plebeius (Lightfoot, 1786) (Mollusca, Psammobiidae) and Iphigenia brasiliana (Lamarck, 1818) (Mollusca, Donacidae) on the Cachoeira River Estuary, Ilhéus, Bahia, Brazil. Brazilian Journal of Biology 70(1): 125-127.

Chung, M.H.; Yoon, W.D. \& Lee, J.-B. 2010. Morphological description of Cyclotella atomus var. marina (Bacillariophyceae): newly reported in Korean waters. Algae 25(2): 57-64.

Denys, L.; Muylaert, K.; Krammer, K.; Joosten, T. \& Reid, M. 2003. Aulacoseira subborealis stat. nov. (Bacillariophyceae): a common but neglected plankton diatom. Nova Hedwigia 77(3-4): 407-427.

Eskinazi-Leça, E.; Cunha, M.G.G.S.; Santiago, M.F.; Borges, G.C.P.; Lima, J.C; Silva, M.H.; Menezes, M.; Ferreira, L.C. \& Aquino, E. 2012. Bacillariophyceae in Lista de Espécies da Flora do Brasil. http:// floradobrasil.jbrj.gov.br/2012/FB120336 (Acesso em 31/07/2012).

Ferrari, F.; Wetzel, C.E.; Ector, L.; Blanco, S.; Viana, J.C.C.; Silva, E.M. \& Bicudo, D.C. 2009. Perinotia diamantina sp. nov., a new diatom species from the Chapada Diamantina, Northeastern Brazil. Diatom Research 24(1): 79-100.

Fontes, I.B.M. \& Araújo, Q.R. 2008. Eficiência na remoção de coliformes na estação de tratamento de esgoto de Ilhéus (Bahia). Geografia 17(1): 127-136.

Garcia, M. \& Odebrecht, C. 2009. Chave dicotômica ilustrada para a identificação de espécies de Thalassiosira Cleve (diatomácea) no estuário da Lagoa dos Patos e área costeira adjacente (Rio Grande do Sul, Brasil). Biota Neotropica 9(2): 239-253.

Genkal, S.I. \& Kiss, K.T. 1993. Morphological variability of the diatom Cyclotella atomus Hustedt var. atomus and C. atomus var. gracilis var. nov. Hydrobiologia 269-270: 39-47.

Germain, H., 1981. Flore des diatomées. Diatomophycées. Paris, Société Nouvelle des Editions Boubée.
Håkansson, H. 2002. A compilation and evaluation of species in the genera Stephanodiscus, Cyclostephanos and Cyclotella with a new genus in the family Stephanodiscaceae. Diatom Research 17(1): 1-139.

Håkansson, H. \& Clarke, K.B. 1997. Morphology and taxonomy of the centric diatom Cyclotella atomus. Nova Hedwigia 65(1-4): 207-219.

Håkansson, H. \& Kling, H. 1994. Cyclotella agassizensis nov. sp. and its relationships to C. quillensis Bailey and other prairie Cyclotella species. Diatom Research 9(2): 289-301.

Hasle, G.R. 1983. The marine planktonic diatoms Thalassiosira oceanica sp. nov. and T. partheneia. Journal of Phycology 19: 220-229.

Hasle, G.R. \& Evensen, D.L. 1976. Brackish water and freshwater species of the diatom genus Skeletonema. II. Skeletonema potamos comb. nov. Journal of Phycology 12: 73-82.

Hasle, G.R. \& Heimdal, B.R. 1970. Some species of the centric diatom genus Thalassiosira studied in the light and electron microscopes. In: Gerloff, J. \& Cholnoky, J.B. Diatomaceae II. Nova Hedwigia 31: 559-589.

Houk, V.; Klee, R. \& Tanaka, H. 2010. Atlas of freshwater centric diatoms with a brief key and descriptions. Part III. Stephanodiscaceae A: Cyclotella, Tertiarius, Discostella. Fottea 10(Supplement): 1-498.

Kiss, K.T.; Ács, E.; Szabó, K.E.; Miracle, M.R. \& Vicente, E. 2007. Morphological observations on Cyclotella distinguenda Hustedt and C. delicatula Hustedt from the core sample of meromictic Karstic Lake of Spain (Lake La Cruz) with aspects of their ecology. Diatom Research 22(2): 287-308.

Kling, H. \& Håkansson, H. 1988. A light and electron microscope study of Cyclotella species (Bacillariophyta) from central and northern Canadian lakes. Diatom Research 3(1): 55-82.

Landucci, M. \& Ludwig, T.A.V. 2005. Diatomáceas de rios da bacia hidrográfica Litorânea, PR, Brasil: Coscinodiscophyceae e Fragilariophyceae. Acta Botanica Brasilica 19(2): 345-357.

Laux, M. \& Torgan, L.C. 2011. Diatomáceas com plastídios no plâncton da foz dos rios do Delta do Jacuí, sul do Brasil: um complemento à taxonomia tradicional. Iheringia, Série Botânica 66(1): 109-132.

Lima, M.C.; Souza, M.F.L.; Eça, G.F. \& Silva, M.A.M. (2010). Export and retention of dissolved inorganic nutrients in the Cachoeira River, Ilhéus, Bahia, Brazil. Journal of Limnology 69(1): 138-145.

Lowe, R.L. 1975. Comparative ultrastructure of the valves of some Cyclotella species (Bacillariophyceae). Journal of Phycology 11: 415-424.

Ludwig, T.A.V. \& Flôres, T.L. 1995. Diatoms of the Rivers from the region to be dammed for the construction of Segredo hydroelectric, Paraná, Brazil. I. Coscinodiscophyceae, Bacillariophyceae (Achnanthales and Eunotiales) and Fragilariophyceae (Meridion and Asterionella). Arquivos de Biologia e Tecnologia 38(2): 631-650.

Ludwig, T.A.V. \& Valente-Moreira, I.M., 1990. A contribution to the knowledge of the diatom flora of Iguaçu Regional Park, Curitiba, Paraná, Brazil: II. Centrales (Bacillariophyceae). Arquivos de Biologia e Tecnologia 33(4): 843-852.

Metzeltin, D. \& Lange-Bertalot, H. 2007. Tropical Diatoms of South America II. Iconographia Diatomologica 18: 1-877.

Morandi, L.L.; Ritter, L.M.O.; Moro, R.S. \& Bicudo, C.E.M. 2006. Criptógamos do Parque Estadual das Fontes do Ipiranga, São Paulo, SP. Algas, 20: Coscinodiscophyceae. Hoehnea 33(1): 115-122.

Moreira-Filho, H. \& Valente-Moreira, I.M. 1981. Avaliação taxonômica e ecológica das diatomáceas (Bacillariophyceae) epífitas em algas pluricelulares obtidas nos litorais dos estados do Paraná, Santa Catarina e São Paulo. Boletim do Museu Botânico Municipal 47: 1-17.

Moreira-Filho, H.; Eskinazi-Leça, E. \& Valente-Moreira, I.M. 1995. Avaliação taxonômica e ecológica das diatomáceas (Chrysophyta - Bacillariophyceae) marinhas e estuarinas nos estados do Espírito Santo, Bahia, Sergipe e Alagoas, Brasil. Biologica Brasilica 6(1-2): 87-110.

Pérez, M.C. \& Odebrecht, C. 2005. The phytoplankton structure of Merin Lagoon: a Subtropical World Biosphere Reserve System (BrasilUruguay). Acta Botanica Croatica 64(2): 247-261.

Pinho, A.G. 2001. Estudo da qualidade das águas do Rio Cachoeira, Região Sul da Bahia. Dissertação. Mestrado em Desenvolvimento Regional e Meio Ambiente, Universidade Estadual de Santa Cruz.

Pinto, T.R. \& Boehs, G. 2008. Nematopsis sp. (Apicomplexa: Eugregarinida) em Mytella guyanensis (Lamarck, 1819) (Bivalvia: Mytilidae) da Região Estuarina do Rio Cachoeira, Ilhéus, Bahia, Brasil. Brazilian Journal of Veterinary Research and Animal Science 45(2): 95-100. 
Raupp, S.V.; Torgan, L.C. \& Baptista, L.R.M. 2006. Composição e variação temporal de diatomáceas (Bacillariophyta) no plâncton da represa de Canastra, sul do Brasil. Iheringia, Série Botânica 61(1-2): 105-134.

Round, F.E.; Crawford, R.M. \& Mann, D.G. 1990. The Diatoms: biology and morphology of the genera. Cambridge, Cambridge University Press.

Sabater, S. \& Klee, R. 1990. Observaciones-sobre diatomeas centrales del fitoplancton del Rio Ebro, con especial interés em algunas pequeñas Cyclotella. Diatom Research 5(1): 141-154.

Sala, S. \& Ramírez-R, J.J. 2008. Cyclotella katiana sp. nov. from La Reina swamp, Parque Nacional Natural Los Katíos, Colombia. Diatom Research 23(1): 147-157.

Sarno, D.; Kooistra, W.H.C.F.; Medlin, L.K.; Percopo, I. \& Zingone, A. 2005. Diversity in the genus Skeletonema (Bacillariophyceae). II. An assessment of the taxonomy of S. costatum-like species with the description of four new species. Journal of Phycology 41: 151-176.

Silva, M.B.; Ribeiro, S.M.M.S. \& Velho, L.F.M. 2009. Testate amoebae composition (Amoebozoa: Rhizopoda) associated to the rizosphere of Eichhornia crassipes (Martius) Solomons (Pontederiaceae) in Cachoeira River, Bahia, Brazil: New records for Northeast. Sitientibus, Série Ciências Biológicas 9(4): 192-203.

Simonsen, R. 1974. The diatom plankton of the Indian Ocean Expedition of R/V “Meteor", 1964-65. "Meteor" Forschungsergbnisse, Reihe D-Biologie 19: 1-66.

Stachura-Suchoples, K. \& Williams, D.M. 2009. Description of Conticribra tricircularis, a new genus and species of Thalassiosirales, with a discussion on its relationship to other continuous cribra species of Thalassiosira Cleve (Bacillariophyta) and its freshwater origin. European Journal of Phycology 44(4): 477-486.

Stoermer, F.E.; Håkansson, H. \& Theriot, E.C. 1987. Cyclostephanos species newly reported from North America: C. tholiformis sp. nov. and C. costatilumbus comb. nov. European Journal of Phycology 22(4): 349-358.

Syvertsen, E.E. \& Hasle, G.R. 1984. Thalassiosira bulbosa Syvertsen sp. nov., an Artic marine diatom. Polar Biology 3: 167-172.

Tanaka, H. 2007. Taxonomic studies of the genera Cyclotella (Kützing) Brébisson, Discostella Houk et Klee and Puncticulata Håkansson in the Family Stephanodiscaceae Glezer et Makarova (Bacillariophyta) in Japan. Bibliotheca Diatomologica 53: 1-204.

Tanimura, Y.; Nagumo, T. \& Kato, M. 2004. A new variety of Cyclotella atomus from Tokyo Bay, Japan; C. atomus var. marina var. nov. Bulletin of National Science Museum, Serie C 30: 5-11.

Theriot, E.; Stoermer, E. \& Håkansson, H. 1987. Taxonomic interpretation of the rimoportula of freshwater genera in the centric diatom family Thalassiosiraceae. Diatom Research 2(2): 251-265.

Torgan, L.C.; Becker, V. \& Santos, C.B. 2009. Skeletonema potamos (Bacillariophyta) in Patos Lagoon, southern Brazil: Taxonomy and distribution. Revista Peruviana de Biologia 16(1): 93-96.

Torgan, L.C. \& Santos, C.B. 2006. Thalassiosira weissflogii (Coscinodiscophyceae, Bacillariophyta) em ambientes lacustres na Planície Costeira do sul do Brasil. Iheringia, Série Botânica 61(1-2): 135-138.

Tremarin, P.I.; Freire, E.G.; Bertolli, L.M. \& Ludwig, T.A.V. 2009. Catálogo das diatomáceas (Ochrophyta-Diatomeae) continentais do Estado do Paraná. Iheringia, Série Botânica 64(2): 79-107.

Tremarin, P.I.; Ludwig, T.A.V. \& Moreira-Filho, H. 2008. Thalassiosirales (Diatomeae) do rio Guaraguaçu, Bacia Litorânea, PR, Brasil. Acta Botanica Brasilica 22(4): 1101-1113

Tremarin, P.I.; Ludwig, T.A.V. \& Torgan, L.C. 2012. Ultrastructure of Aulacoseira brasiliensis sp. nov. (Coscinodiscophyceae) and comparison with related species. Fottea 12(2): 171-188.

Tuji, A. \& Houk, A. 2004. Taxonomy, ultrastructure and biogeography of the Aulacoseira subarctica species complex. Bulletin of National Science Museum 30(2): 35-55.

Tuji, A. \& Williams, D.M. 2007. Type examination of Japanese diatoms described by Friedrich Meister (1913) from Lake Suwa. Bulletin of the National Museum of Natural Science, Serie B 33(2): 69-79.

Weber, C.I. 1970. A new freshwater centric diatom Microsiphona potamos gen. et sp. nov. Journal of Phycology 6: 149-153.

Zimmermann, C. 1913-1919. I-IX Contribuição para o estudo das diatomáceas dos estados unidos do Brazil. Brotéria, Série Botânica 11: 149-164; 12: 5-12; 13: 37-71, 124-146; 14: 85-103, 130-157; 15: 30-45; 16: $8-24,113-122 ; 17: 5-16$ 